UNIVERSIDADE DE BRASÍLIA - UNB

FACULDADE DE ECONOMIA, ADMINISTRAÇÃO, CONTABILIDADE E CIÊNCIA DA INFORMAÇÃO E DOCUMENTAÇÃO - FACE

ARMANDO MELO E SANTOS

\begin{abstract}
ANÁLISE DA DISTORÇÃO DO RESULTADO PRIMÁRIO DO GOVERNO FEDERAL QUANDO APURADO SOB REGIME DE CAIXA
\end{abstract}




\title{
ANÁLISE DA DISTORÇÃO DO RESULTADO PRIMÁRIO DO GOVERNO FEDERAL QUANDO APURADO SOB REGIME DE CAIXA
}

\begin{abstract}
Monografia apresentada ao Programa de Pós-Graduação em Administração (PPGA) da Faculdade de Economia, Administração, Contabilidade e Ciência da Informação e Documentação (FACE), da Universidade de Brasília, como requisito parcial à obtenção do grau de Especialista em Orçamento e Finanças.
\end{abstract}

Orientador: Prof. Otavio Ladeira de Medeiros 


\section{AGRADECIMENTOS}

Ao Prof. Otavio Ladeira de Medeiros, pelas importantes orientações dadas durante todo o estudo e pela disponibilidade em esclarecer prontamente as várias dúvidas encontradas durante o estudo.

Ao Prof. Paulo Henrique Feijó da Silva, pelas valiosas instruções que nortearam os passos iniciais deste estudo.

Ao colega e amigo Luiz Carlos Basbaum, pelas enriquecedoras discussões e pelo apoio dado durante todo o curso.

Por fim, á minha querida esposa, Ludmilla Alves Rodrigues, por todas as palavras de incentivo, pelo carinho e cuidado que sempre me dedicou e, principalmente, pela paciência ao ver diversos planos adiados por causa da "bendita monografia". 


\section{RESUMO}

O objetivo do trabalho é analisar a distorção que ocorre pela metodologia atual de apuração do resultado primário do Governo Federal, a qual é feita considerando apenas o regime de caixa para as receitas e despesas primárias, excluindo do cálculo os Restos a Pagar do exercício financeiro. O estudo detalha, para os exercícios financeiros de 1999 a 2008, os montantes de Restos a Pagar inscritos a cada ano, distinguindo os grupos de despesa e os Restos a Pagar Processados e Não Processados. Foi identificado que o montante de Restos a Pagar, quando comparado com a dotação orçamentária, vem apresentando alta no período de 2003 a 2008, causada principalmente pelos mecanismos de limitação do empenho e a criação dos programas PPI e PAC. Por fim, é concluído que, apesar do sucesso que o setor público vem obtendo em alcançar as metas fiscais definidas, uma parte significativa e crescente do resultado apurado fica comprometido com as despesas inscritas em Restos a Pagar, distorcendo este importante indicador de austeridade fiscal.

Palavras Chave: Política Fiscal - Resultado Primário - Metas Fiscais - Restos a Pagar. 


\section{LISTA DE FIGURAS}

Figura 1 - Comparativo entre estoque orçamentário e estoque de restos a pagar do Governo Federal (1999 - 2008).

Figura 2 - Comparativo entre estoque orçamentário e estoque de restos a pagar para o grupo de despesa "Outras Despesas Correntes" do Governo Federal (1999 - 2008)....

Figura 3 - Comparativo entre estoque orçamentário e estoque de restos a pagar para o grupo de despesa "Investimentos" do Governo Federal (1999 - 2008).

Figura 4 - Comparativo entre estoque de Restos a Pagar Processados Cancelados e Pagos em relação ao estoque Inscrito (2000 - 2008).

Figura 5 - Comparativo entre estoque de Restos a Pagar Não Processados Cancelados e Pagos em relação ao estoque Inscrito (2000 - 2008). 


\section{LISTA DE TABELAS}

Tabela 1 - Comparativo entre estoque orçamentário e estoque de Restos a Pagar do Governo Federal (1999 - 2008).

Tabela 2 - Comparativo entre estoque orçamentário e estoque de Restos a Pagar para o grupo de despesa "Pessoal e Encargos Sociais" do Governo Federal (1999 - 2008)....

Tabela 3 - Comparativo entre estoque orçamentário e estoque de restos a pagar para o grupo de despesa "Juros e encargos da Dívida" do Governo Federal (1999 - 2008).......

Tabela 4 - Comparativo entre estoque orçamentário e estoque de restos a pagar para o grupo de despesa "Outras Despesas Correntes" do Governo Federal (1999 - 2008).

Tabela 5 - Comparativo entre estoque orçamentário e estoque de restos a pagar para o grupo de despesa "Investimentos" do Governo Federal (1999 - 2008).

Tabela 6 - Comparativo entre estoque orçamentário e estoque de restos a pagar para o grupo de despesa "Inversões Financeiras" do Governo Federal (1999 - 2008).

Tabela 7 - Comparativo entre estoque orçamentário e estoque de restos a pagar para o grupo de despesa "Amortização da Dívida" do Governo Federal (1999 - 2008)..

Tabela 8 - Comparação entre os totais de Restos a Pagar pagos e cancelados em relação ao total inscrito a cada exercício (2000 - 2008)....

Tabela 9 - Cálculo do Resultado Primário do Setor Público Consolidado considerando os Restos a Pagar inscritos no exercício (2003 - 2008).

Tabela 10 - Montante de Restos a Pagar considerados no recálculo do Resultado Primário (2003 - 2008). 


\section{SUMÁRIO}

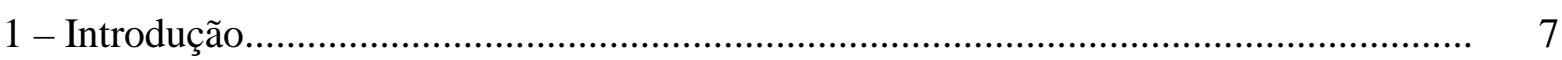

2 - Aspectos relevantes ao estudo do Resultado Primário................................................ 9

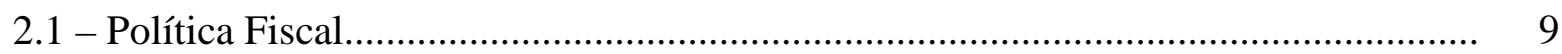

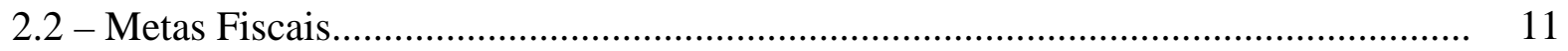

2.3 - Programação e execução Financeira....................................................................... 13

2.4 - Encerramento de Exercício................................................................................. 17

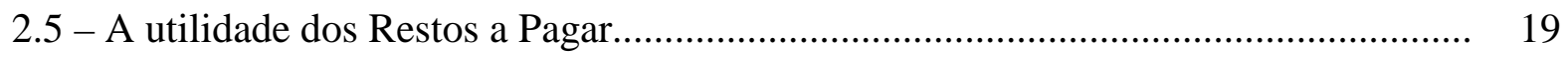

3 - Análise da Dotação Orçamentária confrontada com o estoque de Restos a Pagar....... 20

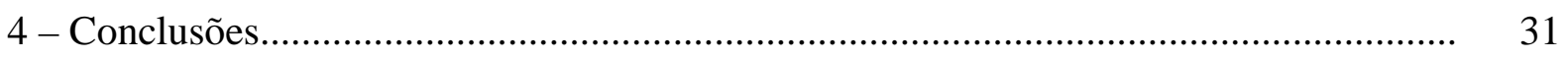

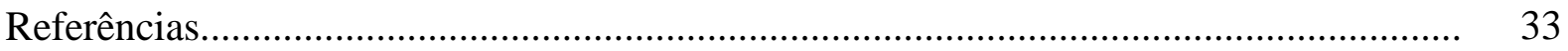




\section{1. - INTRODUÇÃO}

O Resultado Primário é um indicador que mede a austeridade fiscal de um governo. Objetiva-se com sua apuração avaliar se um determinado governo tem a capacidade de gerar receitas em volume suficiente para pagar suas despesas correntes e de investimentos, sem recorrer a um aumento da dívida pública. É definido pela diferença entre: receitas nãofinanceiras, que excluem o recebimento de juros e as receitas de operações de crédito, e despesas não-financeiras, que excluem o pagamento de juros e a amortização de dívidas.

Analisando a metodologia de cálculo do Resultado Primário, percebe-se que quanto menor for o montante das despesas não-financeiras, considerando um mesmo montante de receitas não-financeiras, melhor será o resultado do indicador. Desta forma, ao se apurar o indicador pelo regime de caixa para um determinado exercício, seriam deixadas de lado algumas despesas não-financeiras, os Restos a Pagar pertencentes a este exercício, gerando uma distorção positiva no Resultado Primário apurado.

A política fiscal brasileira tem sido tema de diversas pesquisas científicas. Política fiscal envolve a forma como as receitas públicas são arrecadadas e as despesas públicas são aplicadas pelo governo, e como afetam direta ou indiretamente os vários setores da economia.

Dentre os trabalhos sobre o assunto, Henriques (2006) analisa a forma como as metas fiscais são estabelecidas, e as compara com os resultados apurados. Por fim, conclui que o governo vem cumprindo todas as metas de resultado primário fixadas em acordos com o FMI ou nas diretrizes orçamentárias de cada exercício orçamentário.

Mas a que custo estas metas de resultado primário do governo Federal vêm sendo cumpridas? Giambiagi (2008) revê a trajetória da política fiscal brasileira dos últimos 18 anos e critica, entre outros aspectos, a forma como as estatísticas fiscais são apuradas atualmente. E questiona "até que ponto um sistema de estatísticas montado há aproximadamente 25 anos é o mais adequado para a realidade atual" (GIAMBIAGI, 2008, p.570).

Desta forma, este trabalho pretende enriquecer as discussões sobre a política fiscal brasileira, ao analisar a forma como o resultado primário é apurado atualmente, mas abordando especificamente sua contribuição para a geração de restos a pagar.

Para tentar alcançar o objetivo, será feita uma pesquisa quantitativa e documental, baseada nos dados oficiais divulgados pela Secretaria do Tesouro Nacional. O estudo focará 
os dados dos resultados primários apurados e restos a pagar inscritos nos exercícios financeiros e orçamentários de 1999 a 2008.

O trabalho é dividido em quatro partes. Após esta introdução sobre o tema, são apresentadas e discutidas algumas das principais contribuições científicas sobre os temas Finanças Públicas, Metas Fiscais e Restos a Pagar, além dos principais aspectos legislativos sobre os temas. Na terceira seção tenta-se fazer um comparativo entre as dotações orçamentárias e o montante inscrito em restos a pagar a cada ano. Por fim, na quarta seção, apresentam-se as conclusões sobre o que foi abordado. 


\section{2 - ASPECTOS RELEVANTES AO ESTUDO DO RESULTADO PRIMÁRIO}

Esta seção contém uma análise da produção científica sobre os temas relacionados à execução orçamentária e financeira do Governo Federal, quais sejam: a fixação de metas fiscais, a forma de apuração do Resultado Primário do Governo Federal, seu significado, as principais críticas quanto à forma como é apurado, o significado de restos a pagar e as dificuldades relacionadas à inscrição destes. Também estão dispostos e comentados os principais artigos da legislação vigente sobre o assunto abordado.

\section{1 - Política Fiscal}

Política fiscal envolve a forma como as receitas públicas são arrecadadas e as despesas públicas são aplicadas pelo governo, e como afetam direta ou indiretamente os vários setores da economia. Segundo Albuquerque, Feijó e Medeiros (2008), "política fiscal abrange a administração das receitas, do orçamento e da despesa pública, assim como dos ativos e passivos do governo" (ALBUQUERQUE; FEIJÓ; MEDEIROS, 2008, p.27). São decisões de política fiscal a aplicação de tributação, as decisões de alocação do gasto público, a decisão sobre o tamanho e a abrangência do Estado entre outras.

Assim, a política fiscal é definida, basicamente, pela forma como são aplicados os gastos, a despesa pública, e a forma como os recursos necessários para cobrir estes gastos são arrecadados, a receita pública. Como afirma Albuquerque, Feijó e Medeiros (2008):

\footnotetext{
A política fiscal apresenta dois componentes fundamentais: a receita pública e a despesa pública. No processo de arrecadar receitas e de executar despesas, o governo realiza intervenções expressivas no mercado, promovendo impactos sobre os níveis de emprego, sobre a distribuição da renda, sobre a oferta e procura de bens e serviços, e afetando de forma direta ou indireta os diversos setores da economia. (ALBUQUERQUE; FEIJÓ; MEDEIROS, 2008, p.32)
}

No Brasil, este processo de arrecadar receitas e executar despesas em quaisquer das esferas do setor público, é normatizado por um vasto arcabouço legal, do qual pode-se destacar a Constituição Federal de 1988, em seu Título VI que dispõe sobre a Tributação e o Orçamento, e no Ato das Disposições Constitucionais Transitórias; a Lei 4.320/64, que estatui as normas gerais de Direito Financeiro enquanto a Lei Complementar a que se refere o 
parágrafo $9^{\circ}$ do artigo 165 da Constituição de 1988 não é elaborada e aprovada; e a Lei Complementar $\mathrm{n}^{\mathrm{o}}$ 101/2000, que, a partir de 4 de maio de 2000, estabeleceu normas de finanças públicas para a responsabilidade na gestão Fiscal. Segundo o artigo primeiro, parágrafo primeiro da LRF:

A responsabilidade na gestão fiscal pressupõe a ação planejada e transparente, em que se previnem riscos e corrigem desvios capazes de afetar o equilíbrio das contas públicas, mediante o cumprimento de metas de resultados entre receitas e despesas e a obediência a limites e condições no que tange a renúncia de receita, geração de despesas com pessoal, da seguridade social e outras, dívidas consolidada e mobiliária, operações de crédito, inclusive por antecipação de receita, concessão de garantia e inscrição em Restos a Pagar. (BRASIL, 2000, art $1^{\circ}, \S 1^{\circ}$ ).

Por dispor sobre a responsabilidade na gestão fiscal, estabelecendo limites ao endividamento público e metas para o equilíbrio entre receita e despesa, esta Lei Complementar é conhecida como Lei de Responsabilidade Fiscal (LRF).

No que diz respeito à receita pública, Albuquerque, Feijó e Medeiros afirma:

Parcela relevante da política fiscal diz respeito à forma como o governo atua, junto à sociedade, para obter os recursos necessários à cobertura dos gastos públicos. O primeiro mecanismo de que os governos se valem para obter receitas é a tributação, que pode também ser complementada pela exploração de ativos públicos, como a cobrança por concessões e os aluguéis. Além destas fontes primárias de receitas, os governos cotam usualmente com mecanismos que lhes permitem antecipar receitas futuras. Isso ocorre sempre que o governo utiliza recursos de terceiros, assumindo a obrigação de devolvê-los no futuro.

Esses são os dois mecanismos adotados para a cobertura das despesas públicas: as fontes primárias, em que o governo não contrai obrigação futura, e as fontes de financiamento, em que o governo obtém recursos mediante contração de dívida. Conceitualmente, inclui-se no conjunto de fontes primárias qualquer receita que o governo obtenha e não amplie a sua dívida ou não diminua os seus ativos. (ALBUQUERQUE; FEIJÓ; MEDEIROS, 2008, p.69)

Logo, a receita pública, necessária à cobertura da despesa pública, pode ser obtida pelo governo por meio da tributação e exploração de ativos públicos, esta forma classificada como receita primária ou não-financeira, ou pela contração de obrigação futura, classificada como receita financeira. As receitas primárias correspondem ao total da receita arrecadada, deduzidos os ganhos obtidos em aplicações financeiras, ingressos decorrentes de operações de crédito, recebimentos de empréstimos concedidos, de alienações de patrimônio, e recursos arrecadados de exercícios anteriores. São especificamente compostas por: arrecadação de impostos, taxas, contribuições sociais, receitas de concessões, dividendos, entre outras.

As despesas primárias, ou não-financeiras, por sua vez, correspondem à despesa total, deduzidas as amortizações, juros e encargos da dívida pública mobiliária e contratual, as 
despesas com aquisição de títulos de capital já integralizado e concessão de empréstimos com retorno garantido. Desta forma, também são contabilizados como despesas primárias as despesas extra-orçamentárias de restos a pagar inscritos em exercícios anteriores e pagos no exercício corrente.

Conforme a Portaria Interministerial $n^{\circ} 163 / 2001$ a despesa pública pode ser dividida nos seguintes grupos:

\section{B - GRUPOS DE NATUREZA DE DESPESA}

1 - Pessoal e Encargos Sociais

Despesas de natureza remuneratória decorrentes do efetivo exercício de cargo, emprego ou função de confiança no setor público, do pagamento dos proventos de aposentadorias, reformas e pensões, das obrigações trabalhistas de responsabilidade do empregador, incidentes sobre a folha de salários, contribuição a entidades fechadas de previdência, outros benefícios assistenciais classificáveis neste grupo de despesa, bem como soldo, gratificações, adicionais e outros direitos remuneratórios, pertinentes a este grupo de despesa, previstos na estrutura remuneratória dos militares, e ainda, despesas com o ressarcimento de pessoal requisitado, despesas com a contratação temporária para atender a necessidade de excepcional interesse público e despesas com contratos de terceirização de mão-deobra que se refiram à substituição de servidores e empregados públicos, em atendimento ao disposto no art. $18, \S 1^{\circ}$, da Lei Complementar $n^{\circ} 101$, de 2000;

2 - Juros e Encargos da Dívida

Despesas com o pagamento de juros, comissões e outros encargos de operações de crédito internas e externas contratadas, bem como da dívida pública mobiliária.

3 - Outras Despesas Correntes

Despesas com aquisição de material de consumo, pagamento de diárias, contribuições, subvenções, auxílio alimentação, auxílio-transporte, além de outras despesas da categoria econômica "Despesas Correntes" não classificáveis nos demais grupos de natureza de despesa;

4 - Investimentos

Despesas com o planejamento e a execução de obras, inclusive com a aquisição de imóveis considerados necessários à realização destas últimas, e com a aquisição de instalações, equipamentos e material permanente.

5 - Inversões Financeiras

Despesas com a aquisição de imóveis ou bens de capital já em utilização; aquisição de títulos representativos do capital de empresas ou entidades de qualquer espécie, já constituídas, quando a operação não importe aumento do capital; e com a constituição ou aumento do capital de empresas.

6 - Amortização da Dívida

Despesas com o pagamento e/ou refinanciamento do principal e da atualização monetária ou cambial da dívida pública interna e externa, contratual ou mobiliária.

(BRASIL, Ministério da Fazenda. Secretaria do Tesouro Nacional e Ministério do Planejamento, Orçamento e Gestão. Secretaria de Orçamento Federal, 2001, Anexo II, Capítulo II, item B).

\section{2- Metas Fiscais}

A LRF complementa a Lei 4.320/64 e a Constituição que, em seu artigo 165, parágrafo segundo, diz que Leis de iniciativa do Poder Executivo estabelecerão as diretrizes orçamentárias. Segundo a Constituição: 
A lei de diretrizes orçamentárias compreenderá as metas e prioridades da administração pública federal, incluindo as despesas de capital para o exercício financeiro subseqüente, orientará a elaboração da lei orçamentária anual, disporá sobre as alterações na legislação tributária e estabelecerá a política de aplicação das agências financeiras oficiais de fomento. (BRASIL, 1988, art. 165, § $2^{\circ}$ )

Complementando a Constituição, a LRF, em seu artigo quarto, detalha os requisitos que devem constar na Lei de Diretrizes Orçamentárias, e, em seu parágrafo quarto, rege:

\footnotetext{
Integrará o projeto de lei de diretrizes orçamentárias Anexo de Metas Fiscais, em que serão estabelecidas metas anuais, em valores correntes e constantes, relativas a receitas, despesas, resultados nominal e primário e montante da dívida pública, para o exercício a que se referirem e para os dois seguintes. (BRASIL, 2000, art. $4^{\circ}$, $\left.\S 4^{\circ}\right)$.
}

Dentre as Metas Fiscais, uma das mais importantes é a meta de Resultado Primário. O Resultado Primário mede a austeridade fiscal de um governo. Objetiva-se com sua apuração avaliar se um determinado governo tem a capacidade de gerar receitas em volume suficiente para pagar suas despesas correntes e de investimentos, sem recorrer a um aumento da dívida pública. É definido pela diferença entre receitas não-financeiras, que excluem recebimento de juros e receitas de operações de crédito, e despesas não-financeiras, que excluem o pagamento de juros e a amortização de dívidas.

O resultado primário do Governo Federal é calculado pela diferença entre as receitas e despesas primárias do Tesouro Nacional e do Regime Geral de Previdência Social, diferença esta apurada pelo regime de caixa, ou seja, apenas as receitas primárias realizadas e as despesas primárias pagas compõem o cálculo do resultado.

O motivo da apuração do Resultado Primário do Governo Federal ser pelo regime de caixa vem da necessidade de aproximação entre o valor calculado pelo Banco Central, que realiza a apuração denominada "abaixo da linha", e o apurado pela Secretaria do tesouro Nacional, pela apuração "acima da linha”.

É importante lembrar que receitas e despesas provenientes de transferências entre entidades que compõem o ente federativo não são incluídas no cálculo, de forma a evitar a ocorrência de dupla contagem.

Caso a diferença entre as receitas e despesas primárias seja positiva, tem-se um superávit primário, que, na prática, significa que o governo arrecada mais do que gasta, podendo utilizar este excesso para amortizar a dívida pública. Por outro lado, caso a diferença 
seja negativa tem-se um déficit primário, indicando que o governo gasta mais do que arrecada, tendo que recorrer a endividamento para cobrir esta despesa excedente.

Em relação ao cumprimento das metas de resultado primário, Henriques (2006) comprova que:

Desde os Acordos com o Fundo Monetário Internacional, até a Lei de Responsabilidade Fiscal, o Governo sistematicamente cumpriu todas as metas de resultado primário, quer estivessem estabelecidas nos Acordos com o FMI, quer constassem dos anexos de metas fiscais determinados pela LRF. (HENRIQUES, 2006, p. 12).

De que forma estas metas foram cumpridas, foi analisado por Giambiagi (2008) ao rever a trajetória da política fiscal no Brasil desde 1991 até 2008. Dentre vários desafios listados por ele, propõe-se repensar as estatísticas fiscais. Giambiagi (2008) justifica:

A pergunta-chave é se faz sentido, do ponto de vista empresarial das estatais, continuar acumulando ativos financeiros que diminuem a dívida líquida, apenas pelo fato de que, se estes se transformarem em investimentos, serão captados pela estatística fiscal como uma redução do superávit primário consolidado. (GIAMBIAGI, 2008, p. 571).

Silva e Pires (2006) também criticam a forma como o resultado primário é apurado e seus efeitos no crescimento da economia, e propõem sua substituição pela apuração da poupança em conta corrente do governo. Segundo Silva e Pires (2006):

... propõe-se permutar a meta fiscal embasada no superávit primário pela meta de poupança em conta corrente do governo. O conceito de poupança em conta corrente do governo consiste na retirada dos investimentos públicos do cálculo do superávit primário. Em virtude de não penalizar a elevação do estoque de capital, um dos determinantes do crescimento econômico, o conceito de poupança em conta corrente do governo mostra-se economicamente mais adequado do que o superávit primário. (SILVA e PIRES, 2006, p. 614).

\section{3- Programação e Execução Financeira}

Para alcançar as metas fiscais estabelecidas na Lei de Diretrizes Orçamentárias e corrigir os desvios que possam afetar o equilíbrio das contas públicas, a legislação permite ao governo fazer uso de alguns instrumentos de controle das contas públicas. Especificamente para o controle do fluxo das despesas públicas, pode-se dizer que o governo dispõe de três represas: a limitação de crédito para as dotações orçamentárias, por meio do planejamento que 
tem como instrumentos principais o Plano Plurianual (PPA), a Lei de Diretrizes Orçamentárias (LDO) e a Lei Orçamentária Anual (LOA); a limitação do empenho de despesas, e a limitação do pagamento.

A primeira das represas é composta por todo o ciclo de elaboração da Lei Orçamentária Anual. Nesta Lei, de iniciativa do Poder Executivo, são distribuídos os créditos para a execução das despesas, tendo como insumo as diretrizes definidas na Lei de Diretrizes Orçamentárias e o planejamento do Plano Plurianual. Para financiar as dotações orçamentárias, é feita a previsão da receita que será auferida pelo governo para todo o exercício a que se refere à LOA. Claro que o ciclo de elaboração da LOA é bem mais complexo do que o que acaba de ser exposto, e deve considerar inúmeras variáveis, tais como as vinculações de receitas e a existência de despesas não discricionárias. Mas o que é pertinente ao trabalho quanto à limitação da dotação orçamentária é que:

- A LOA fixa a dotação orçamentária para um determinado exercício, e esta dotação pode ser agrupada segundo os grupos de natureza de despesa, já citados, determinados pela Portaria Interministerial $n^{\mathrm{o}} 163 / 2001$;

- A LOA também contém uma previsão da receita a ser auferida no exercício, que permita a execução integral da dotação orçamentária e o alcance das metas fiscais definidas na LDO;

- Nenhuma despesa pública pode ser empenhada sem que haja prévio e suficiente crédito orçamentário definido, conforme determinado pelo artigo 167 da Constituição Federal que em seu inciso II veda "a realização de despesas ou a assunção de obrigações diretas que excedam os créditos orçamentários ou adicionais" (BRASIL, 1988, art. 167, inciso II), e reforçado pelo artigo 59 da Lei $n^{\circ} 4.320 / 64$ : “o empenho da despesa não poderá exceder o limite dos créditos concedidos" (BRASIL, 1964, art. 59).

Caso o processo de estimar a receita pública de cada exercício fosse livre de falhas, a simples execução do orçamento seria suficiente para o cumprimento das metas e a manutenção do equilíbrio das finanças públicas, restando ao governo apenas o papel de compatibilizar o fluxo financeiro da arrecadação da receita em relação à execução da despesa. Para esta função, a Lei n ${ }^{\circ} 4.320 / 64$, nos artigos 47 e 48, institui:

Art. 47. Imediatamente após a promulgação da Lei de Orçamento e com base nos limites nela fixados, o Poder Executivo aprovará um quadro de cotas trimestrais da despesa que cada unidade orçamentária fica autorizada a utilizar.

Art. 48 A fixação das cotas a que se refere o artigo anterior atenderá aos seguintes objetivos: 
a) assegurar às unidades orçamentárias, em tempo útil a soma de recursos necessários e suficientes a melhor execução do seu programa anual de trabalho;

b) manter, durante o exercício, na medida do possível o equilíbrio entre a receita arrecadada e a despesa realizada, de modo a reduzir ao mínimo eventuais insuficiências de tesouraria. (BRASIL, 1964, art. 47 e 48)

Mas deve-se reconhecer que a estimativa de receita disposta na LOA pode conter erros, seja por basear-se em premissas imprecisas, ou pelo risco do acontecimento de eventos imprevistos que possam frustrar parte da arrecadação, tais como crises políticas ou econômicas. Reconhecendo esta possibilidade, a LRF, por meio dos artigos $8^{\circ}$ e $9^{\circ}$, normatizou dois importantes instrumentos para o controle da execução orçamentária e financeira: a Programação Financeira e o Cronograma de Execução Mensal de Desembolso. Conforme a Lei Complementar $n^{0} 101 / 2000$, artigos $8^{\circ}$ e $9^{\circ}$ :

Art. 8 Até trinta dias após a publicação dos orçamentos, nos termos em que dispuser a lei de diretrizes orçamentárias e observado o disposto na alínea c do inciso I do art. $4^{\circ}$, o Poder Executivo estabelecerá a programação financeira e o cronograma de execução mensal de desembolso. (...)

Art. 9 Se verificado, ao final de um bimestre, que a realização da receita poderá não comportar o cumprimento das metas de resultado primário ou nominal estabelecidas no Anexo de Metas Fiscais, os Poderes e o Ministério Público promoverão, por ato próprio e nos montantes necessários, nos trinta dias subseqüentes, limitação de empenho e movimentação financeira, segundo os critérios fixados pela lei de diretrizes orçamentárias. (BRASIL, 2000, art. $8^{\circ}$ e $9^{\circ}$ )

Assim, o governo possui mais duas represas para controle do gasto público: o limite de empenho e o limite de pagamento. A possibilidade de limitar o empenho é especialmente importante, pois caso o controle fosse restrito à limitação do pagamento, o risco à austeridade fiscal persistiria, como assinala Albuquerque, Feijó e Medeiros.

Uma vez que a execução da despesa exige o cumprimento de diversas etapas, como a licitação, o empenho, a produção dos bens e serviços, a liquidação e o pagamento, há um longo hiato de tempo entre a assunção dos compromissos e o respectivo pagamento. Se o controle se efetivar somente na fase do pagamento, o risco de acumulação de compromissos não pagos se mantém, por que não se garantiu que a contratação e a produção de bens e serviços fosse também controlada. (ALBUQUERQUE; FEIJÓ; MEDEIROS, 2008, p. 337-338)

Mas nem todas as despesas são passíveis de limitação de empenho. Alguns gastos possuem exigências determinadas em Lei quanto à obrigatoriedade de sua realização. Alguns destes são determinados até pelas próprias LRF e LDO, e, assim, ficam fora do alcance do mecanismo de limitação de empenho pelo governo. Sobre esta rigidez de gastos, Albuquerque, Feijó e Medeiros observam: 
O corte de despesas no setor público muitas vezes encontra dificuldades intransponíveis, em decorrência da ausência de flexibilidade para redução do valor de determinados gastos. A própria Lei de Responsabilidade Fiscal determina (artigo $9^{\circ}, \S 2^{\circ}$ ) que não serão objeto de limitação as despesas decorrentes de obrigações constitucionais e legais do ente, as destinações ao pagamento do serviço da dívida e as ressalvadas na LDO. Adicionalmente, o pagamento da folha de pessoal, que representa um dos maiores itens da despesa nos orçamentos públicos, apresenta flexibilidade extremamente limitada. Dessa forma, a limitação de empenho com vistas ao adequado ajuste fiscal se viabiliza quase exclusivamente mediante ajuste nos valores das dotações para despesas de custeio e de investimento. (ALBUQUERQUE; FEIJÓ; MEDEIROS, 2008, p. 344-345)

Dentre as despesas ressalvadas pela LDO, destacam-se as relativas a dois programas especiais de investimento do governo federal: o PPI, Programa Piloto de Investimentos, e o PAC, Programa de Aceleração do Crescimento.

O PPI tem sua origem nos acordos feitos entre o Brasil e o FMI, de 1998 a 2004. Nos termos deste acordo, o Brasil se comprometia a alcançar determinadas metas, mas poderia abater parte deste resultado na execução de um conjunto de projetos de investimento, considerados prioritários para possibilitar uma continuidade do crescimento econômico do país. Cabe destacar que a alternativa deste abatimento nunca foi utilizada. Com o fim do acordo, em 2004, o PPI foi incluído no orçamento de 2005, e continuou nos orçamentos seguintes. Para integrar a carteira do PPI, o projeto deve cumprir uma série de exigências, como citado por Albuquerque, Feijó e Medeiros:

... os projetos são avaliados sob aspectos como: custo-benefício; impacto direto e indireto sobre os níveis de emprego, de renda, de produção, de investimento e de comércio exterior; estimativa de geração de receitas tributárias nos três níveis de governo; custos tributários incorridos pelos executores do projeto; possibilidade de retorno financeiro mediante concessão, tarifa ou outras formas de recuperação de custos; período de depreciação do projeto; custos anuais de manutenção; benefícios em termos de redução de despesas públicas quando da conclusão do projeto; riscos jurídicos, regulatórios e ambientais, assim como aqueles relativos a atrasos, custos, contratos, demandas, obsolescência tecnológica e de passivos contingentes. (ALBUQUERQUE; FEIJÓ; MEDEIROS, 2008, p. 61)

O PAC, instituído pelo decreto $\mathrm{n}^{0}$ 6.025, de 22 de janeiro de 2007, tem como objetivo acelerar o ritmo de crescimento da economia brasileira. Segundo o artigo $1^{\mathrm{o}}$ deste decreto, constituem o PAC "medidas de estímulo ao investimento privado, ampliação dos investimentos públicos em infra-estrutura e voltadas à melhoria da qualidade do gasto público e ao controle da expansão dos gastos correntes no âmbito da Administração Pública Federal" (BRASIL, 2007, $\operatorname{art} .1^{\circ}$ ). O PAC, então, pela sua dimensão, é superior ao incorporar os projetos que compõem o PPI. 


\section{4- Encerramento de exercício}

Segundo o artigo 34 da Lei $\mathrm{n}^{\mathrm{o}} 4.320 / 64$, “o exercício financeiro coincidirá com o ano civil”. (BRASIL, 1964, art. 34). Desta forma, o exercício financeiro tem início no dia $1^{\circ}$ de janeiro e termina no dia 31 de dezembro de cada ano. A mesma Lei, em seu artigo 35, também determina:

Art. 35. Pertencem ao exercício financeiro:

I - as receitas nele arrecadadas;

II - as despesas nele legalmente empenhadas. (BRASIL, 1964, art. 35)

O artigo 35 da Lei $n^{\circ}$ 4.320/64 não deixa dúvidas ao reconhecer como pertencentes a um exercício financeiro as receitas arrecadadas e o total de despesas empenhadas neste exercício, estabelecendo que o critério a ser usado na apuração dos resultados do exercício é o de caixa para as receitas e competência para as despesas. As despesas empenhadas no exercício e não pagas até o último dia do ano são inscritas em Restos a Pagar.

A Lei de Responsabilidade Fiscal estabelece limites rígidos para a dívida pública consolidada, para a dívida pública mobiliária e seu refinanciamento, para operações de crédito e concessões de garantia. Como um exemplo destes limites, em seu artigo 29, parágrafo $4^{\circ}$, a Lei Complementar $n^{0} 101 / 2000$ determina que "o refinanciamento do principal da dívida mobiliária não excederá, ao término de cada exercício financeiro, o montante do final do exercício anterior, somado ao das operações de crédito autorizadas no orçamento para este efeito e efetivamente realizadas, acrescido de atualização monetária" (BRASIL,2000, art 29, § $\left.4^{\mathrm{o}}\right)$.

Mas quanto aos Restos a Pagar, que fazem parte da chamada dívida flutuante da União, o único limite expresso na Lei de Responsabilidade Fiscal, está determinado em seu artigo 42. Segundo este artigo:

\footnotetext{
É vedado ao titular de Poder ou órgão referido no art. 20, nos últimos dois quadrimestres do seu mandato, contrair obrigação de despesa que não possa ser cumprida integralmente dentro dele, ou que tenha parcelas a serem pagas no exercício seguinte sem que haja suficiente disponibilidade de caixa para este efeito.(BRASIL, 2000, art 42)
}

Desta forma, os limites para a inscrição de restos a pagar compreendem apenas os dois últimos quadrimestres do mandato, e, ainda assim, o limite diz respeito apenas às despesas contraídas neste período. Não há limite para despesas contraídas antes deste prazo. 
A lei $\mathrm{n}^{0} 4.320$ define Restos a Pagar como: "consideram-se Restos a Pagar as despesas empenhadas, mas não pagas até o dia 31 de dezembro distinguindo-se as processadas das não processadas" (BRASIL, 1964, art. 36).

Assim, as despesas inscritas em restos a pagar classificam-se em:

- Restos a pagar Processados - são as despesas que já se encontram liquidadas, mas não foram pagas dentro do exercício financeiro e orçamentário onde ocorreu o empenho. São despesas em que o credor já cumpriu com as suas obrigações e tem reconhecido como líquido e certo o seu direito ao respectivo pagamento.

- Restos a pagar não processados - são as despesas que se encontram empenhadas, possuem já identificados a especificação, o credor e o montante, mas ainda não tiveram sua liquidação e seu pagamento. São despesas que ainda dependem da entrega dos bens ou serviços pelo fornecedor ou, ainda que tal entrega tenha se efetivado, o direito do credor ainda não foi apurado e reconhecido.

Em quaisquer das situações, o futuro pagamento da despesa inscrita em restos a pagar se realizará de forma extra-orçamentária, ou seja, não mais será objeto de apropriação orçamentária no exercício vigente. Assim os restos a pagar constituem despesas vinculadas a empenho de anos anteriores lançadas no Orçamento em respeito ao princípio da universalidade. No entanto, o seu pagamento em exercício seguinte é fato extra-orçamentário, à luz do orçamento que está sendo executado. Tudo isso em respeito ao princípio da anualidade do Orçamento, como afirmam Albuquerque, Feijó e Medeiros (2008).

Silva (2003) apresenta os reflexos da inscrição de restos a Pagar no Balanço Orçamentário e propõe um tratamento para este tipo de despesa pública. Segundo ele:

\footnotetext{
A inscrição de restos a pagar não evidencia corretamente os valores de execução das despesas públicas por tipo de crédito demonstradas no Balanço Orçamentário da União, porque foram consideradas despesas executadas no ano de inscrição e podem ser canceladas no exercício seguinte. (SILVA, 2003, p. 66).
}

Complementa afirmando que:

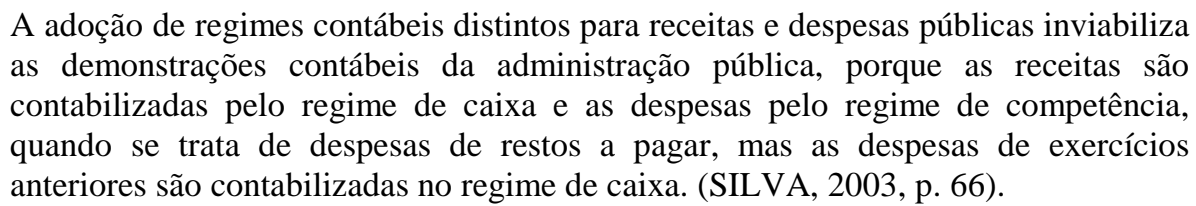

E conclui que: 
Considerando as distorções que podem apresentar os restos a pagar, e a obrigatoriedade de disponibilidade de caixa, para serem pagas no exercício seguinte, podemos considerar que, no âmbito federal, não devem haver restos a pagar. $\mathrm{O}$ tratamento julgado mais adequado é considerar as despesas de restos a pagar como despesas de exercícios anteriores ou utilizar o reempenho. (SILVA, 2003, p. 66).

Desta forma, Silva expõe as distorções que os Restos a Pagar apresentam, dentre elas a possibilidade de cancelamento destas despesas, impossibilitando uma apuração precisa do resultado do exercício em que foram empenhadas, e a distorção do regime contábil; e conclui como solução para o problema a utilização do reempenho.

\section{5- A utilidade dos Restos a Pagar}

São enumerados diversos problemas relacionados à inscrição de Restos a Pagar, dentre eles a dificuldade de gestão de despesas extra-orçamentárias, a distorção das metas fiscais, e a concorrência entre o pagamento destas despesas e a execução orçamentária do exercício vigente. Diante de tantas dificuldades, por que esta prática já não foi extinta?

Para responder esta pergunta, deve-se relembrar a forma como ocorre o planejamento e a execução orçamentária e financeira. A Lei 4.320/64 determina que o exercício financeiro coincida com o ano civil. Este também é o período de vigência da LOA, peça central de todo o planejamento orçamentário e financeiro, como já foi explicado anteriormente. Isso significa afirmar que qualquer crédito constante na LOA perde a validade no dia 31 de dezembro do ano de sua abertura, caso não tenha sido utilizado.

Uma vez extinto o crédito, novo pedido deve ser feito à Secretaria de Planejamento, o qual concorrerá novamente com inúmeros outros projetos, tendo que seguir todo o árduo ciclo do planejamento orçamentário, passando pela revisão do legislativo e pela sanção do executivo. Desta forma, não executar um crédito concedido em um exercício significa, para o gestor do projeto, o risco de jamais conseguir concluir este projeto, dadas as dificuldades de incluí-lo no novo planejamento.

Daí a importância da alternativa de inscrição de Restos a Pagar. Para o gestor de um projeto, o ato de empenhar uma despesa para inscrevê-la em Restos a Pagar significa garantir a continuidade deste projeto nos limites dos créditos concedidos pela LOA, ainda que o exercício financeiro chegue ao fim. 


\section{3 - ANÁlise DA DOTAÇÃO ORÇAMENTÁRIA CONFRONTADA COMO ESTOQUE DE RESTOS A PAGAR}

São considerados os dados referentes aos exercícios de 1999, quando as estatísticas fiscais tornaram-se mais abrangentes, até os referentes ao último exercício apurado, 2008. Apenas para efeito comparativo, também serão usados os dados do primeiro trimestre de 2009. Estes dados encontram-se disponíveis no portal da Secretaria do Tesouro Nacional, nos Relatórios resumidos da execução orçamentária do governo federal (RRO), disponíveis no sítio separados por mês desde 2002, e por ano de 2001 a 1995.

Os RRO foram previstos pelo artigo 165, parágrafo terceiro da Constituição Federal, que diz que "o Poder Executivo publicará, até trinta dias após o encerramento de cada bimestre, relatório resumido da execução orçamentária” (BRASIL, 1988, art. 165, § 3º). Este parágrafo foi complementado pelos artigos 52 e 53 da LRF, os quais, dentre várias exigências, determinam que conste do relatório: o balanço orçamentário, especificando as receitas por fonte e as despesas por grupo de natureza; demonstrativos relativos a resultados nominal e primário, e relativos a Restos a Pagar.

Para cada exercício considerado, foram coletados do RRO do mês de dezembro de cada ano: as dotações atualizadas das despesas orçamentárias, informadas no anexo "Balanço Orçamentário"; e o montante de restos a pagar processados e não-processados, informados na tabela "Demonstrativo dos restos a pagar por grupo de despesa". Os montantes foram coletados pela classificação feita no relatório, segundo os seguintes grupos de despesa: "Pessoal e Encargos Sociais", "Juros e Encargos da Dívida”, "Outras Despesas Correntes”, "Investimentos", "Inversões Financeiras", “Amortização/Refinanciamento da Dívida" e "Reserva de Contingência" (apenas para as despesas orçamentárias).

Dos relatórios, foi possível retirar os valores da dotação atualizada, autorizada no orçamento de cada exercício, e os estoques de Restos a Pagar processados e não processados inscritos em cada ano. A partir destes dados, foi possível comparar, em termos percentuais, os estoques de restos a pagar em relação à dotação orçamentária autorizada a cada exercício. A tabela 1 e a figura 1, abaixo, apresentam o resultado deste comparativo. No caso desta tabela e desta figura, foram consideradas as dotações atualizadas do orçamento, incluídos os créditos adicionais, e o montante líquido de restos a pagar, excluídos do montante inscrito os restos a pagar cancelados até o último mês de cada exercício. É importante lembrar que os Restos a 
Pagar são despesas extra-orçamentárias, ou seja, não compõem a dotação orçamentária do exercício comparado na tabela 1 .

Tabela 1 - Comparativo entre estoque orçamentário e estoque de Restos a Pagar do Governo Federal $(1999$ - 2008)

\begin{tabular}{c|c|c|c|c|c|c|c}
\hline \multirow{2}{*}{$\begin{array}{c}\text { Exercício } \\
\text { Orçamentário }\end{array}$} & $\begin{array}{c}\text { Dotação } \\
\text { Orçamentária }\end{array}$ & \multicolumn{2}{|c|}{$\begin{array}{c}\text { Restos a Pagar } \\
\text { Processados }\end{array}$} & \multicolumn{2}{c|}{$\begin{array}{c}\text { Restos a Pagar Não } \\
\text { Processados }\end{array}$} & \multicolumn{2}{c}{$\begin{array}{c}\text { Total de Restos a } \\
\text { Pagar }\end{array}$} \\
\cline { 2 - 7 } & $\mathbf{R}$ bilhões & $\mathbf{R} \$$ bilhões & $\%$ & $\mathbf{R} \$$ bilhões & $\%$ & R\$ bilhões & $\%$ \\
\hline 1999 & 635,72 & 2,40 & $0,38 \%$ & 21,02 & $3,31 \%$ & 23,41 & $3,68 \%$ \\
\hline 2000 & $1.030,30$ & 1,80 & $0,17 \%$ & 22,28 & $2,16 \%$ & 24,08 & $2,34 \%$ \\
\hline 2001 & 973,96 & 1,87 & $0,19 \%$ & 10,47 & $1,07 \%$ & 12,33 & $1,27 \%$ \\
\hline 2002 & 708,93 & 2,24 & $0,32 \%$ & 16,38 & $2,31 \%$ & 18,62 & $2,63 \%$ \\
\hline 2003 & $1.099,97$ & 2,93 & $0,27 \%$ & 7,53 & $0,68 \%$ & 10,47 & $0,95 \%$ \\
\hline 2004 & 646,71 & 7,59 & $1,17 \%$ & 6,14 & $0,95 \%$ & 13,73 & $2,12 \%$ \\
\hline 2005 & 698,95 & 3,92 & $0,56 \%$ & 13,00 & $1,86 \%$ & 16,92 & $2,42 \%$ \\
\hline 2006 & 886,08 & 3,95 & $0,45 \%$ & 22,00 & $2,48 \%$ & 25,95 & $2,93 \%$ \\
\hline 2007 & 929,68 & 4,88 & $0,52 \%$ & 30,35 & $3,27 \%$ & 35,23 & $3,79 \%$ \\
\hline 2008 & $1.077,47$ & 6,14 & $0,57 \%$ & 48,95 & $4,54 \%$ & 55,08 & $5,11 \%$ \\
\hline
\end{tabular}

Obs.: Em 2009, os valores registrados até março foram: 2,46\% para Restos a Pagar Processados, 6,48\% para Restos a Pagar Não Processados e um total inscrito em Restos a Pagar de 8,90\%.

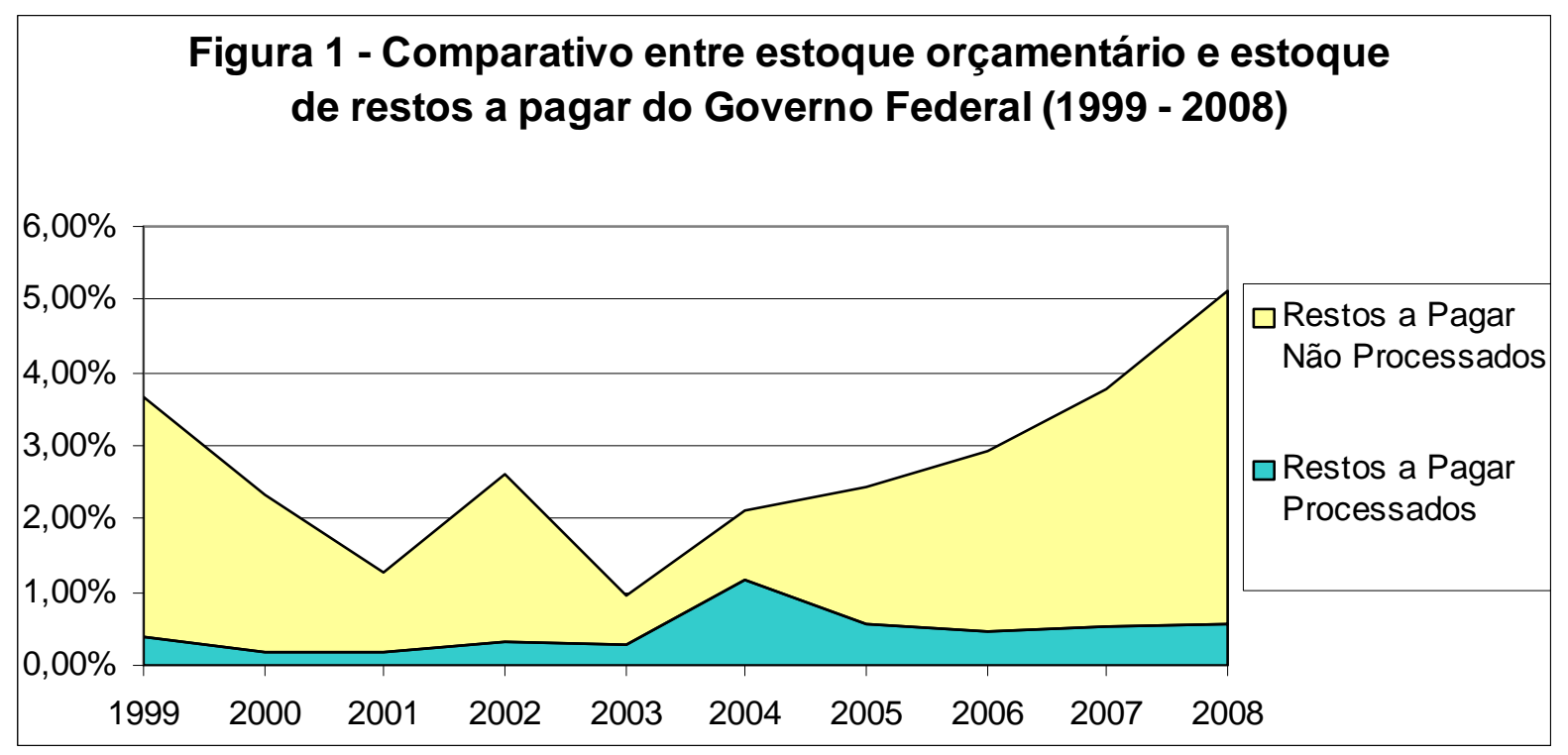

Nota-se pela tabela 1 e pela figura 1, um aumento do montante de Restos a Pagar a cada Exercício Orçamentário, a partir de 2004. Isto indica que a execução da despesa vem sendo progressivamente atrasada para os exercícios seguintes. O fato de a maior parte do montante de Restos a Pagar ser da categoria Não Processado pode indicar também um 
progressivo retardo da liberação de empenho de despesas, o que fez com que o ciclo de execução despesa não pudesse ser executado completamente até o final do exercício.

Para detalhar este comparativo, foi possível extrair dos mesmos relatórios os estoques da dotação orçamentária e restos a pagar divididos por grupos de despesa, a saber: "Pessoal e Encargos Sociais", "Juros e Encargos da Dívida”, “Outras Despesas Correntes", "Investimentos", "Inversões Financeiras" e "Amortização/Refinanciamento da Dívida". A partir destes valores, e utilizando a mesma metodologia de cálculo da tabela 1, foram elaboradas as tabelas e figuras abaixo.

\begin{tabular}{|c|c|c|c|c|c|c|c|}
\hline \multirow{2}{*}{$\begin{array}{c}\text { Exercício } \\
\text { Orçamentário }\end{array}$} & \multirow{2}{*}{$\begin{array}{c}\begin{array}{c}\text { Dotação } \\
\text { Orçamentária }\end{array} \\
\mathbf{R} \$ \text { bilhões }\end{array}$} & \multicolumn{2}{|c|}{$\begin{array}{l}\text { Restos a Pagar } \\
\text { Processados }\end{array}$} & \multicolumn{2}{|c|}{$\begin{array}{c}\text { Restos a Pagar Não } \\
\text { Processados }\end{array}$} & \multicolumn{2}{|c|}{$\begin{array}{c}\text { Total de Restos a } \\
\text { Pagar }\end{array}$} \\
\hline & & $\mathbf{R} \$$ bilhões & $\%$ & R\$ bilhões & $\%$ & R\$ bilhões & $\%$ \\
\hline 1999 & 51,98 & - & $0,00 \%$ & 0,02 & $0,04 \%$ & 0,02 & $0,04 \%$ \\
\hline 2000 & 58,98 & - & $0,00 \%$ & 0,13 & $0,21 \%$ & 0,13 & $0,21 \%$ \\
\hline 2001 & 65,95 & - & $0,00 \%$ & 0,45 & $0,69 \%$ & 0,45 & $0,69 \%$ \\
\hline 2002 & 75,32 & 0,05 & $0,06 \%$ & 0,79 & $1,05 \%$ & 0,83 & $1,11 \%$ \\
\hline 2003 & 79,30 & 0,02 & $0,03 \%$ & 0,49 & $0,62 \%$ & 0,51 & $0,64 \%$ \\
\hline 2004 & 90,30 & 0,02 & $0,02 \%$ & 0,34 & $0,38 \%$ & 0,36 & $0,40 \%$ \\
\hline 2005 & 101,68 & 0,33 & $0,33 \%$ & 0,43 & $0,42 \%$ & 0,76 & $0,75 \%$ \\
\hline 2006 & 107,17 & 0,13 & $0,12 \%$ & 0,40 & $0,37 \%$ & 0,53 & $0,50 \%$ \\
\hline 2007 & 119,35 & 0,04 & $0,03 \%$ & 0,73 & $0,61 \%$ & 0,77 & $0,65 \%$ \\
\hline 2008 & 134,97 & 0,43 & $0,32 \%$ & 1,06 & $0,79 \%$ & 1,50 & $1,11 \%$ \\
\hline
\end{tabular}

Obs.: Em 2009 os valores registrados até março foram: 0,75\% para Restos a Pagar Processados, 0,93\% para Restos a Pagar Não Processados e um total inscrito em Restos a Pagar de 1,69 \%.

Tabela 3 - Comparativo entre estoque orçamentário e estoque de restos a pagar para o grupo de despesa "Juros e encargos da Dívida" do Governo Federal (1999 - 2008)

\begin{tabular}{c|c|c|c|c|c|c|c}
\hline \multirow{2}{*}{$\begin{array}{c}\text { Exercício } \\
\text { Orçamentário }\end{array}$} & $\begin{array}{c}\text { Dotação } \\
\text { Orçamentária }\end{array}$ & \multicolumn{2}{|c|}{$\begin{array}{c}\text { Restos a Pagar } \\
\text { Processados }\end{array}$} & \multicolumn{2}{c}{$\begin{array}{c}\text { Restos a Pagar Não } \\
\text { Processados }\end{array}$} & \multicolumn{2}{c}{$\begin{array}{c}\text { Total de Restos a } \\
\text { Pagar }\end{array}$} \\
\cline { 2 - 8 } & $\mathbf{R} \$$ bilhões & $\mathbf{R} \$$ bilhões & $\%$ & $\mathbf{R} \$$ bilhões & $\%$ & $\mathbf{R} \$$ bilhões & $\%$ \\
\hline 1999 & 52,11 & 0,00 & $0,00 \%$ & 0,00 & $0,00 \%$ & 0,00 & $0,00 \%$ \\
\hline 2000 & 78,13 & 0,00 & $0,00 \%$ & 0,00 & $0,00 \%$ & 0,00 & $0,00 \%$ \\
\hline 2001 & 71,53 & 0,01 & $0,02 \%$ & 0,03 & $0,04 \%$ & 0,04 & $0,06 \%$ \\
\hline 2002 & 58,64 & 0,02 & $0,03 \%$ & 0,00 & $0,00 \%$ & 0,02 & $0,03 \%$ \\
\hline 2003 & 93,70 & 0,03 & $0,03 \%$ & 0,01 & $0,01 \%$ & 0,04 & $0,04 \%$ \\
\hline 2004 & 117,36 & 0,02 & $0,02 \%$ & 0,00 & $0,00 \%$ & 0,02 & $0,02 \%$ \\
\hline 2005 & 110,84 & 0,02 & $0,02 \%$ & 0,00 & $0,00 \%$ & 0,02 & $0,02 \%$ \\
\hline 2006 & 179,87 & 0,00 & $0,00 \%$ & 0,00 & $0,00 \%$ & 0,00 & $0,00 \%$ \\
\hline 2007 & 168,18 & 0,04 & $0,02 \%$ & 0,00 & $0,00 \%$ & 0,04 & $0,02 \%$ \\
\hline 2008 & 152,22 & 0,03 & $0,02 \%$ & 0,00 & $0,00 \%$ & 0,03 & $0,02 \%$ \\
\hline
\end{tabular}

Obs.: Em 2009 os valores registrados até março foram: 0,02\% para Restos a Pagar Processados, 0,02\% para Restos a Pagar Não Processados e um total inscrito em Restos a Pagar de 0,04\%. 
Tabela 4 - Comparativo entre estoque orçamentário e estoque de restos a pagar para o grupo de despesa "Outras Despesas Correntes" do Governo Federal (1999 - 2008)

\begin{tabular}{c|c|c|c|c|c|c|c}
\hline \multirow{2}{*}{$\begin{array}{c}\text { Exercício } \\
\text { Orçamentário }\end{array}$} & $\begin{array}{c}\text { Dotação } \\
\text { Orçamentária }\end{array}$ & \multicolumn{2}{|c|}{$\begin{array}{c}\text { Restos a Pagar } \\
\text { Processados }\end{array}$} & \multicolumn{2}{c}{$\begin{array}{c}\text { Restos a Pagar Não } \\
\text { Processados }\end{array}$} & \multicolumn{2}{c}{$\begin{array}{c}\text { Total de Restos a } \\
\text { Pagar }\end{array}$} \\
\cline { 2 - 8 } & $\mathbf{R} \$$ bilhões & $\mathbf{R} \$$ bilhões & $\%$ & $\mathbf{R} \$$ bilhões & $\%$ & R\$ bilhões & $\%$ \\
\hline 1999 & 135,98 & 1,69 & $1,24 \%$ & 2,19 & $1,61 \%$ & 3,88 & $2,85 \%$ \\
\hline 2000 & 157,03 & 1,23 & $0,78 \%$ & 3,37 & $2,15 \%$ & 4,60 & $2,93 \%$ \\
\hline 2001 & 181,52 & 1,16 & $0,64 \%$ & 4,60 & $2,53 \%$ & 5,76 & $3,17 \%$ \\
\hline 2002 & 216,28 & 0,92 & $0,42 \%$ & 4,59 & $2,12 \%$ & 5,51 & $2,55 \%$ \\
\hline 2003 & 245,45 & 1,21 & $0,49 \%$ & 3,20 & $1,30 \%$ & 4,41 & $1,80 \%$ \\
\hline 2004 & 283,62 & 3,92 & $1,38 \%$ & 2,87 & $1,01 \%$ & 6,80 & $2,40 \%$ \\
\hline 2005 & 341,01 & 2,03 & $0,60 \%$ & 5,39 & $1,58 \%$ & 7,42 & $2,18 \%$ \\
\hline 2006 & 385,84 & 1,71 & $0,44 \%$ & 9,69 & $2,51 \%$ & 11,40 & $2,95 \%$ \\
\hline 2007 & 428,52 & 2,29 & $0,53 \%$ & 13,45 & $3,14 \%$ & 15,73 & $3,67 \%$ \\
\hline 2008 & 488,91 & 1,83 & $0,37 \%$ & 17,49 & $3,58 \%$ & 19,32 & $3,95 \%$ \\
\hline
\end{tabular}

Obs.: Em 2009 os valores registrados até março foram: 3,52 \% para Restos a Pagar Processados, 4,78 \% para Restos a Pagar Não Processados e um total inscrito em Restos a Pagar de 8,30 \%.

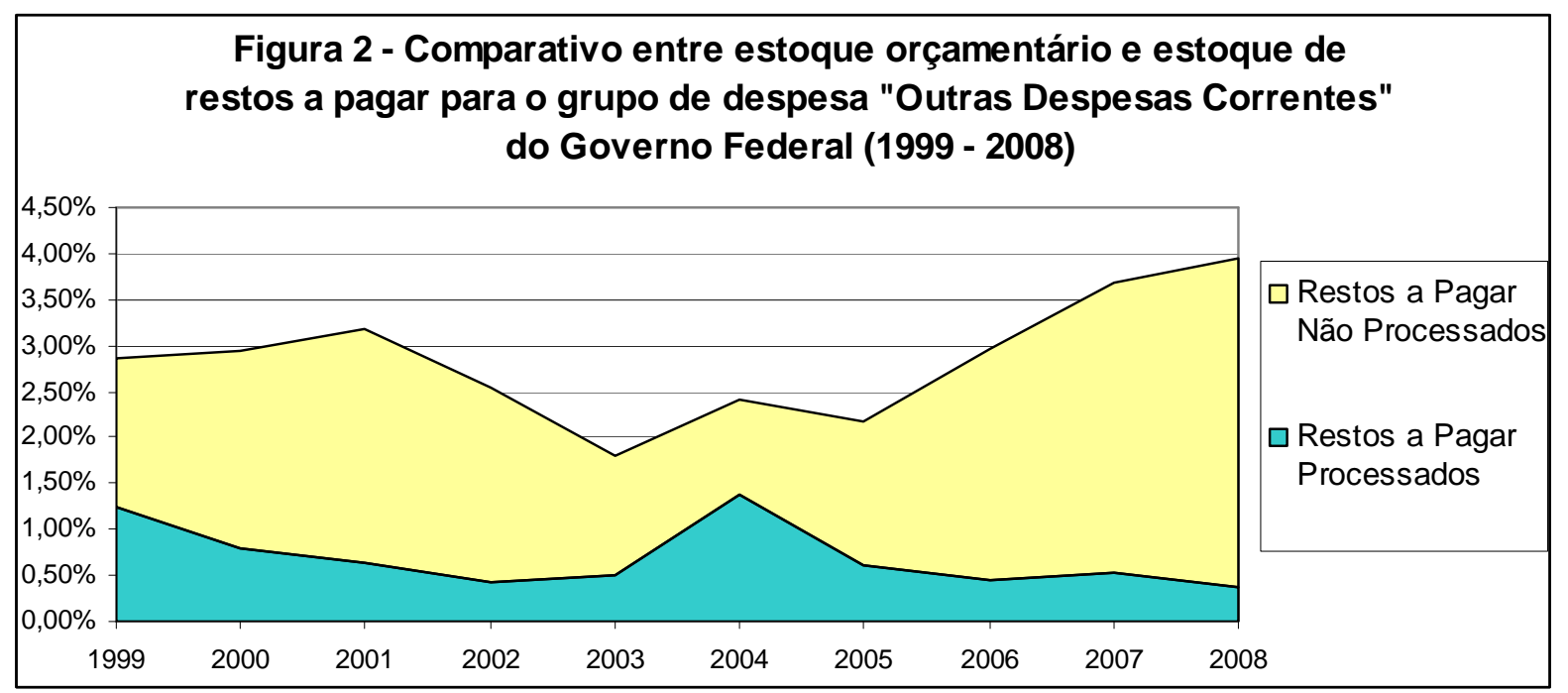


Tabela 5 - Comparativo entre estoque orçamentário e estoque de restos a pagar para o grupo de despesa "Investimentos" do Governo Federal (1999 - 2008)

\begin{tabular}{c|c|c|c|c|c|c|c}
\hline \multirow{2}{*}{$\begin{array}{c}\text { Exercício } \\
\text { Orçamentário }\end{array}$} & $\begin{array}{c}\text { Dotação } \\
\text { Orçamentária }\end{array}$ & \multicolumn{2}{|c|}{$\begin{array}{c}\text { Restos a Pagar } \\
\text { Processados }\end{array}$} & \multicolumn{2}{c}{$\begin{array}{c}\text { Restos a Pagar Não } \\
\text { Processados }\end{array}$} & \multicolumn{2}{c}{$\begin{array}{c}\text { Total de Restos a } \\
\text { Pagar }\end{array}$} \\
\cline { 2 - 8 } & $\mathbf{R} \$$ bilhões & $\mathbf{R} \$$ bilhões & $\%$ & $\mathbf{R} \$$ bilhões & $\%$ & R\$ bilhões & $\%$ \\
\hline 1999 & 9,08 & 0,64 & $7,01 \%$ & 1,04 & $11,49 \%$ & 1,68 & $18,50 \%$ \\
\hline 2000 & 14,72 & 0,52 & $3,53 \%$ & 2,45 & $16,65 \%$ & 2,97 & $20,18 \%$ \\
\hline 2001 & 19,50 & 0,33 & $1,69 \%$ & 4,70 & $24,09 \%$ & 5,03 & $25,78 \%$ \\
\hline 2002 & 18,18 & 0,68 & $3,76 \%$ & 7,78 & $42,77 \%$ & 8,46 & $46,54 \%$ \\
\hline 2003 & 13,95 & 1,54 & $11,05 \%$ & 2,51 & $18,01 \%$ & 4,05 & $29,06 \%$ \\
\hline 2004 & 15,25 & 3,39 & $22,23 \%$ & 1,68 & $11,05 \%$ & 5,07 & $33,27 \%$ \\
\hline 2005 & 23,37 & 1,16 & $4,96 \%$ & 5,08 & $21,74 \%$ & 6,24 & $26,70 \%$ \\
\hline 2006 & 26,15 & 1,75 & $6,69 \%$ & 10,62 & $40,64 \%$ & 12,37 & $47,32 \%$ \\
\hline 2007 & 42,05 & 2,41 & $5,72 \%$ & 13,56 & $32,24 \%$ & 15,96 & $37,96 \%$ \\
\hline 2008 & 47,67 & 3,49 & $7,31 \%$ & 26,48 & $55,53 \%$ & 29,96 & $62,84 \%$ \\
\hline
\end{tabular}

Obs.: Em 2009 os valores registrados até março foram: 8,94 \% para Restos a Pagar Processados, 71,33 \% para Restos a Pagar Não Processados e um total inscrito em Restos a Pagar de 80,27\%.

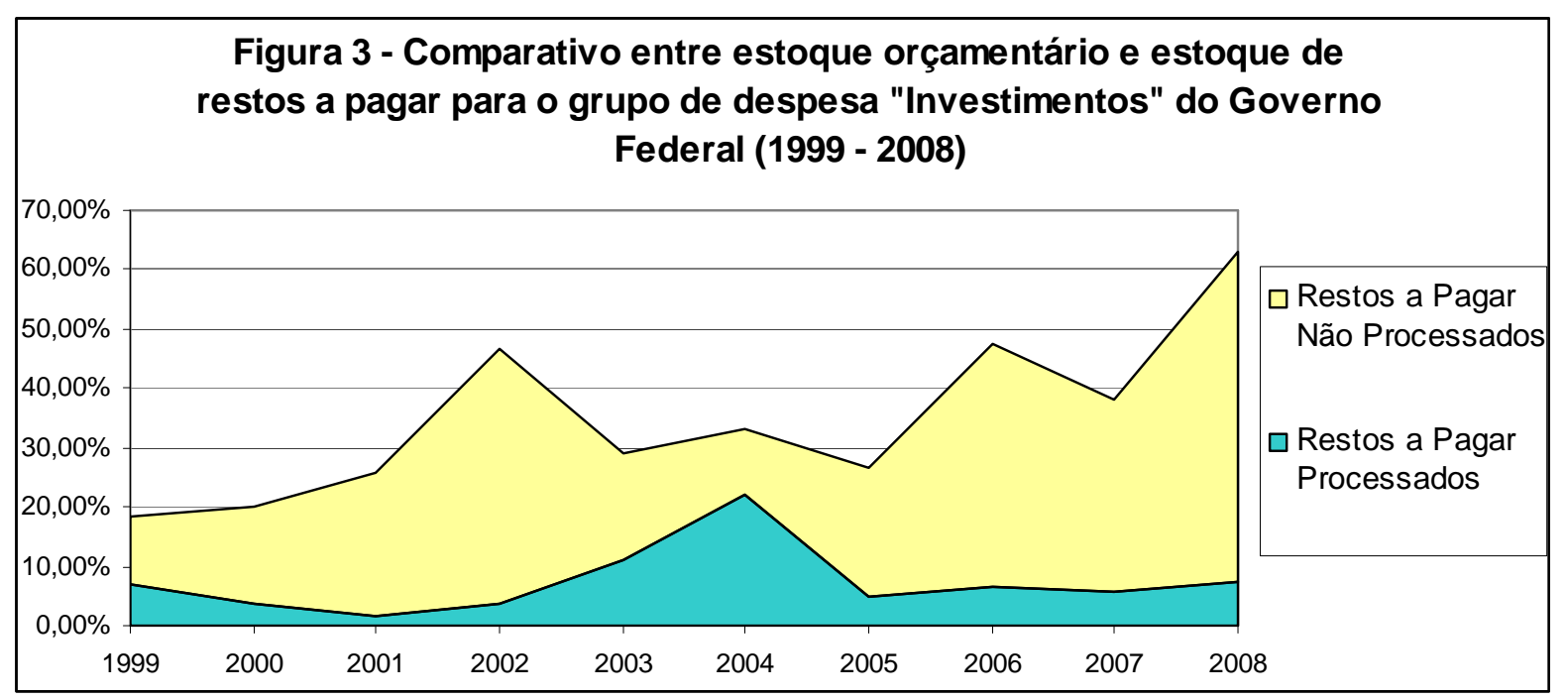




\begin{tabular}{|c|c|c|c|c|c|c|c|}
\hline \multicolumn{8}{|c|}{$\begin{array}{c}\text { Tabela } 6 \text { - Comparativo entre estoque orçamentário e estoque de restos a pagar para o grupo } \\
\text { de despesa "Inversões Financeiras" do Governo Federal }(1999-2008)\end{array}$} \\
\hline \multirow{2}{*}{$\begin{array}{l}\text { Exercício } \\
\text { Orçamentário }\end{array}$} & \multirow{2}{*}{\begin{tabular}{|c|}
$\begin{array}{c}\text { Dotação } \\
\text { Orçamentária }\end{array}$ \\
$\mathbf{R} \$$ bilhões \\
\end{tabular}} & \multicolumn{2}{|c|}{$\begin{array}{l}\text { Restos a Pagar } \\
\text { Processados }\end{array}$} & \multicolumn{2}{|c|}{$\begin{array}{l}\text { Restos a Pagar Não } \\
\text { Processados }\end{array}$} & \multicolumn{2}{|c|}{$\begin{array}{l}\text { Total de Restos a } \\
\text { Pagar }\end{array}$} \\
\hline & & $R$ \$ bilhões & $\%$ & R\$ bilhões & $\%$ & R\$ bilhões & $\%$ \\
\hline 1999 & 60,75 & 0,07 & $0,11 \%$ & 17,76 & $29,24 \%$ & 17,83 & $29,35 \%$ \\
\hline 2000 & 12,43 & 0,05 & $0,37 \%$ & 16,32 & $131,22 \%$ & 16,36 & $131,59 \%$ \\
\hline 2001 & 25,13 & 0,10 & $0,41 \%$ & 0,62 & $2,46 \%$ & 0,72 & $2,87 \%$ \\
\hline 2002 & 25,21 & 0,06 & $0,26 \%$ & 3,22 & $12,78 \%$ & 3,29 & $13,03 \%$ \\
\hline 2003 & 27,97 & 0,11 & $0,39 \%$ & 1,32 & $4,72 \%$ & 1,43 & $5,11 \%$ \\
\hline 2004 & 36,32 & 0,21 & $0,58 \%$ & 1,24 & $3,42 \%$ & 1,45 & $4,00 \%$ \\
\hline 2005 & 34,49 & 0,35 & $1,01 \%$ & 2,10 & $6,10 \%$ & 2,45 & $7,10 \%$ \\
\hline 2006 & 30,70 & 0,28 & $0,92 \%$ & 1,28 & $4,18 \%$ & 1,56 & $5,09 \%$ \\
\hline 2007 & 38,68 & 0,07 & $0,18 \%$ & 2,62 & $6,77 \%$ & 2,69 & $6,95 \%$ \\
\hline 2008 & 49,70 & 0,33 & $0,66 \%$ & 3,92 & $7,88 \%$ & 4,25 & $8,54 \%$ \\
\hline
\end{tabular}

Obs.: Em 2009 os valores registrados até março foram: 1,43 \% para Restos a Pagar Processados, 10,95 \% para Restos a Pagar Não Processados e um total inscrito em Restos a Pagar de 12,38\%.

\begin{tabular}{c|c|c|c|r|r|r|r}
\hline \multicolumn{2}{c}{$\begin{array}{c}\text { Tabela } 7 \text { - Comparativo entre estoque orçamentário e estoque de restos a pagar para o grupo } \\
\text { de despesa "Amortização da Dívida" do Governo Federal (1999 - 2008) }\end{array}$} \\
\hline \multirow{2}{*}{$\begin{array}{c}\text { Exercício } \\
\text { Orçamentário }\end{array}$} & $\begin{array}{c}\text { Dotação } \\
\text { Orçamentária }\end{array}$ & $\begin{array}{c}\text { Restos a Pagar } \\
\text { Processados }\end{array}$ & $\begin{array}{c}\text { Restos a Pagar Não } \\
\text { Processados }\end{array}$ & $\begin{array}{c}\text { Total de Restos a } \\
\text { Pagar }\end{array}$ \\
\cline { 2 - 8 } & $\mathbf{R} \mathbf{\$}$ bilhões & $\mathbf{R} \$$ bilhões & $\%$ & $\mathbf{R} \$$ bilhões & $\%$ & $\mathbf{R} \$$ bilhões & $\%$ \\
\hline 1999 & 325,81 & 0,00 & $0,00 \%$ & 0,00 & $0,00 \%$ & 0,00 & $0,00 \%$ \\
\hline 2000 & 709,00 & 0,00 & $0,00 \%$ & 0,02 & $0,00 \%$ & 0,02 & $0,00 \%$ \\
\hline 2001 & 610,34 & 0,01 & $0,00 \%$ & 0,07 & $0,01 \%$ & 0,08 & $0,01 \%$ \\
\hline 2002 & 310,74 & 0,01 & $0,00 \%$ & 0,00 & $0,00 \%$ & 0,02 & $0,01 \%$ \\
\hline 2003 & 625,86 & 0,02 & $0,00 \%$ & 0,00 & $0,00 \%$ & 0,02 & $0,00 \%$ \\
\hline 2004 & 83,46 & 0,02 & $0,02 \%$ & 0,00 & $0,00 \%$ & 0,02 & $0,02 \%$ \\
\hline 2005 & 68,73 & 0,02 & $0,03 \%$ & 0,00 & $0,00 \%$ & 0,02 & $0,03 \%$ \\
\hline 2006 & 138,28 & 0,08 & $0,06 \%$ & 0,00 & $0,00 \%$ & 0,08 & $0,06 \%$ \\
\hline 2007 & 109,57 & 0,04 & $0,03 \%$ & 0,00 & $0,00 \%$ & 0,04 & $0,03 \%$ \\
\hline 2008 & 182,35 & 0,03 & $0,02 \%$ & 0,00 & $0,00 \%$ & 0,03 & $0,02 \%$ \\
\hline
\end{tabular}

Obs.: Em 2009 os valores registrados até março foram: 0,05 \% para Restos a Pagar Processados, 0,23 \% para Restos a Pagar Não Processados e um total inscrito em Restos a Pagar de 0,27 \%.

Analisando as tabelas 2, 3 e 7, nota-se que os grupos de despesa "Pessoal e Encargos Sociais", "Juros e Encargos da Dívida" e "Amortização/Refinanciamento da Dívida" são pouco representativos no montante de Restos a Pagar, sendo equivalentes a, no máximo, $1 \%$ da dotação orçamentária. Este é um resultado natural, considerando tratar-se de grupos de despesa que possuem pouca discricionariedade para limitação de empenho. 
Já as tabelas 4, e 6 demonstram que os grupos de despesa "Outras Despesas Correntes" e "Inversões Financeiras" são mais representativos na composição dos Restos a Pagar, contudo, raramente superam $15 \%$ da dotação orçamentária, somando-se o montante de restos a pagar processados e não processados.

No entanto, comparando as demais tabelas à tabela 5, nota-se que o grupo de despesa que apresenta maior volume de inscrições em restos a pagar, quando confrontado com o montante orçamentário para o mesmo grupo de despesa, é o grupo "Investimentos".

Destas tabelas, cabem as seguintes análises:

A primeira análise diz respeito ao contingenciamento de empenho. Por se tratar fundamentalmente de despesas discricionárias, despesas de investimento, custeio e inversões financeiras são mais fáceis de ser limitadas ou adiadas do que, por exemplo, despesas com pagamento de pessoal ou de pagamento a juros da dívida. Assim, estas despesas seriam, normalmente, contingenciadas até que se houvesse certeza de que não haveria frustração de receita ou qualquer outro risco ao alcance das metas fiscais do exercício. Por conta deste atraso, não haveria prazo hábil para a execução de todo o ciclo da despesa dentro do exercício fiscal, restando ao final deste, despesas ainda pendentes de pagamento.

A segunda análise diz respeito à criação do PPI, Programa Piloto de Investimentos, e do PAC, Programa de Aceleração de Investimentos. Os projetos do PAC e do PPI não possuem limitação de empenho ou pagamento, e o acúmulo destes nos restos a pagar seria explicado pelo próprio ritmo de execução dos projetos, que em sua maioria correspondem a projetos de longo prazo, com duração plurianuais. Projetos de longa duração sempre estão sujeitos a riscos, seja por atraso de fornecedores, pela dificuldade de emissão de licenças, por externalidades climáticas, ou mesmo pela dificuldade em se projetar os fluxos de despesas para a execução destes. Estes riscos normalmente não geram muitos transtornos quando se trata de investimento privado, mas para projetos públicos, há o entrave do final do exercício financeiro, quando os créditos não utilizados são cancelados. Assim, para que não se percam os créditos orçamentários, há o empenho das despesas relativas a estes projetos, ainda que sua execução tenha sofrido atrasos.

Os efeitos do contingenciamento podem ser observados nas tabelas 4, 5 e 6, e melhor visualizados nas figuras 2 e 3 . Mas o excesso de inscrições em Restos a Pagar para o grupo de despesa "Investimentos", visto na tabela 5 e figura 3, pode ser melhor explicado pelos efeitos do PPI, sentido em todos os exercícios analisados; e do PAC, que explicaria o expressivo avanço das inscrições para o exercício 2008. 


\begin{tabular}{|c|c|c|c|c|c|c|c|c|c|c|}
\hline \multirow{3}{*}{ Exercício } & \multicolumn{5}{|c|}{ RP Processados } & \multicolumn{5}{|c|}{ RP Não Processados } \\
\hline & \multirow{2}{*}{\begin{tabular}{|c} 
Inscritos \\
$\mathrm{R} \$$ \\
bilhões
\end{tabular}} & \multicolumn{2}{|c|}{ Cancelados } & \multicolumn{2}{|c|}{ Pagos } & \multirow{2}{*}{$\begin{array}{l}\text { Inscritos } \\
\mathrm{R} \$ \\
\text { bilhões }\end{array}$} & \multicolumn{2}{|c|}{ Cancelados } & \multicolumn{2}{|c|}{ Pagos } \\
\hline & & $\begin{array}{c}\mathrm{R} \$ \\
\text { bilhões }\end{array}$ & $\%$ & $\begin{array}{c}\mathrm{R} \$ \\
\text { bilhões }\end{array}$ & $\%$ & & $\begin{array}{c}\mathrm{R} \$ \\
\text { bilhões }\end{array}$ & $\%$ & $\begin{array}{c}\mathrm{R} \$ \\
\text { bilhões }\end{array}$ & $\%$ \\
\hline 2000 & 1,80 & - & $0,00 \%$ & 1,22 & $68,11 \%$ & 22,96 & 0,68 & $2,97 \%$ & 21,81 & $94,97 \%$ \\
\hline 2001 & 1,87 & - & $0,00 \%$ & 0,92 & $49,26 \%$ & 13,15 & 2,68 & $20,38 \%$ & 9,10 & $69,20 \%$ \\
\hline 2002 & 3,20 & 0,96 & $29,93 \%$ & 1,90 & $59,39 \%$ & 22,10 & 5,72 & $25,88 \%$ & 15,57 & $70,46 \%$ \\
\hline 2003 & 3,59 & 0,66 & $18,28 \%$ & 2,46 & $68,51 \%$ & 14,50 & 6,97 & $48,06 \%$ & 6,53 & $45,06 \%$ \\
\hline 2004 & 7,93 & 0,34 & $4,29 \%$ & 6,23 & $78,57 \%$ & 23,75 & 17,62 & $74,15 \%$ & 5,67 & $23,88 \%$ \\
\hline 2005 & 4,34 & 0,42 & $9,70 \%$ & 2,80 & $64,59 \%$ & 17,30 & 4,31 & $24,89 \%$ & 9,93 & $57,41 \%$ \\
\hline 2006 & 4,85 & 0,90 & $18,49 \%$ & 3,08 & $63,60 \%$ & 34,13 & 12,13 & $35,55 \%$ & 18,03 & $52,82 \%$ \\
\hline 2007 & 5,24 & 0,36 & $6,82 \%$ & 3,51 & $66,98 \%$ & 38,69 & 8,34 & $21,55 \%$ & 21,88 & $56,54 \%$ \\
\hline 2008 & 7,03 & 0,89 & $12,73 \%$ & 3,45 & $49,07 \%$ & 55,43 & 6,48 & $11,70 \%$ & 31,31 & $56,49 \%$ \\
\hline $\begin{array}{l}\text { Média - } \\
2000 \text { a } \\
2008\end{array}$ & 4,43 & 0,50 & $11,14 \%$ & 2,84 & $63,12 \%$ & 26,89 & 7,21 & $29,46 \%$ & 15,54 & $58,54 \%$ \\
\hline
\end{tabular}

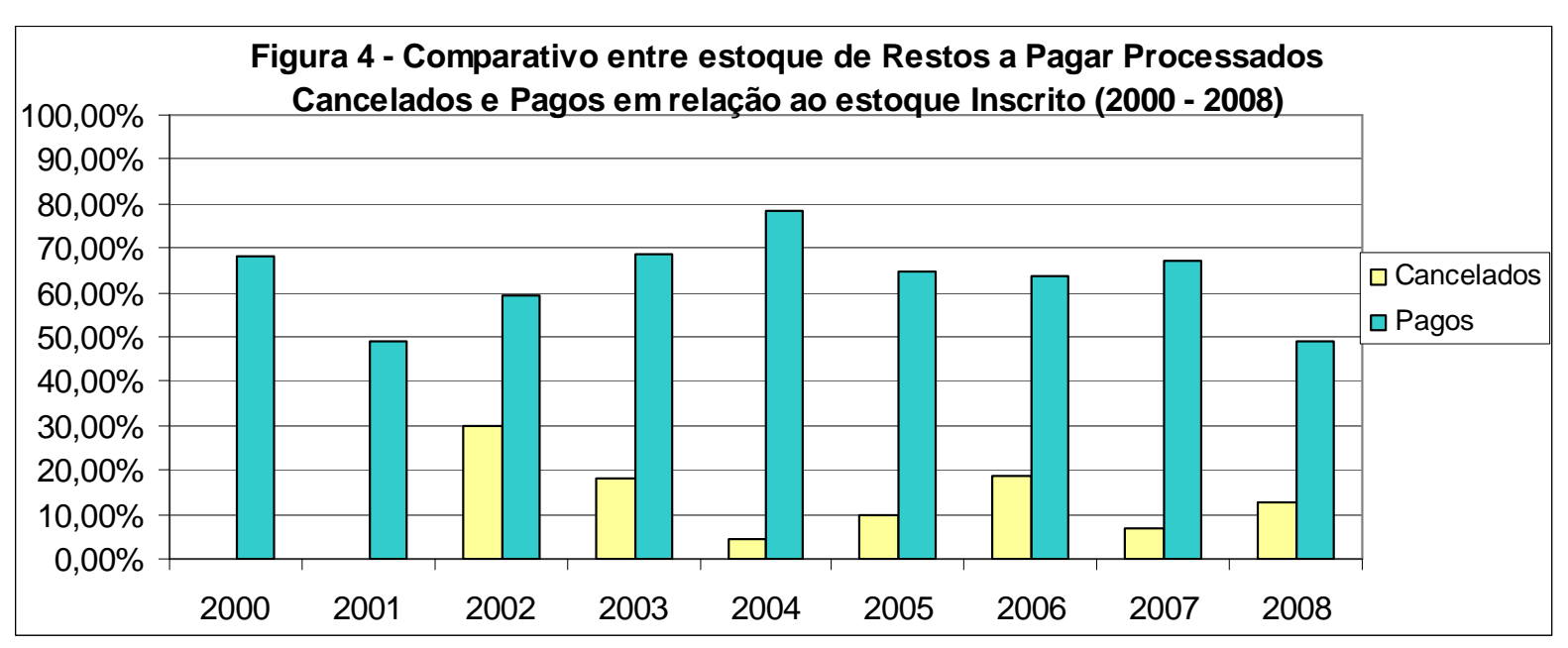




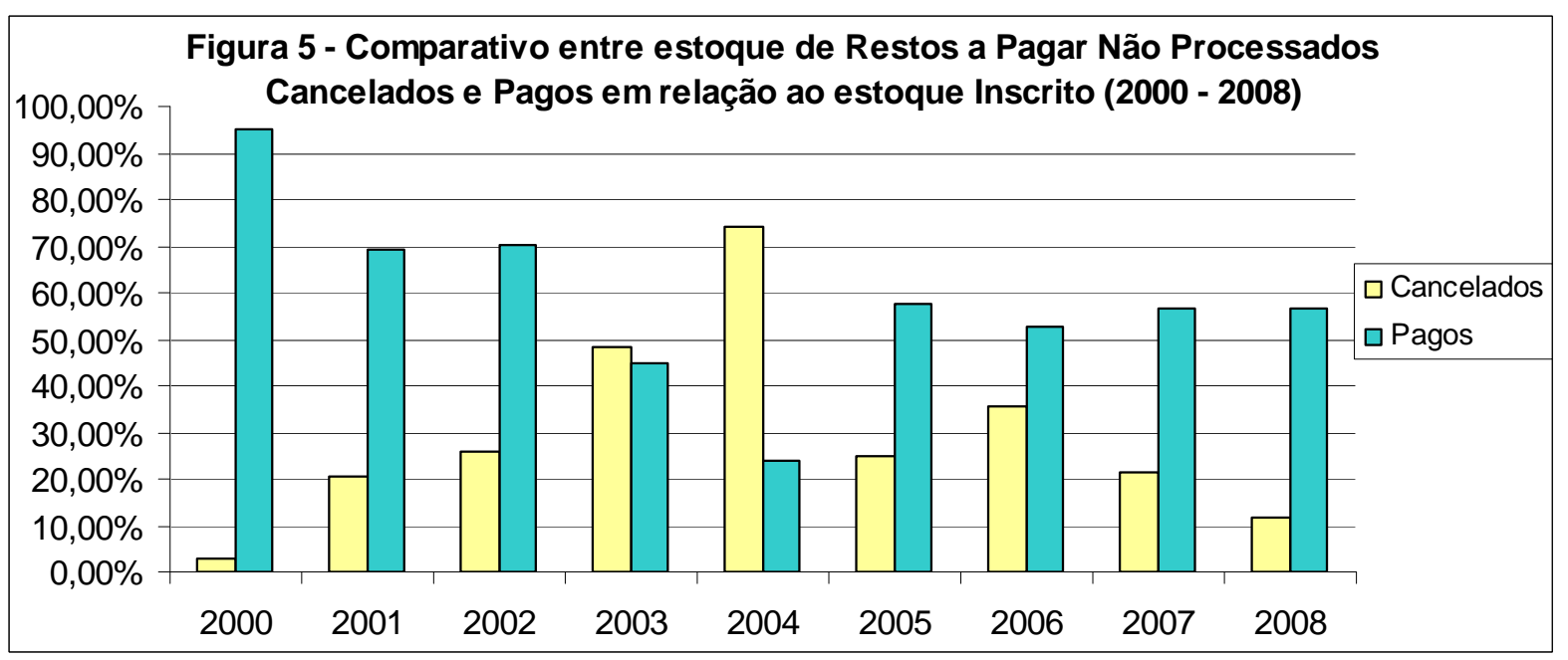

Na tabela 8 são comparados os totais de restos a pagar cancelados e pagos, em relação aos totais inscritos a cada exercício, separados por restos a pagar processados e não processados. Nas figuras 4 e 5, os valores da tabela 8 são dispostos graficamente, para melhor visualização dos dados. Na última linha da tabela 8 é calculada a média percentual dos valores cancelados e inscritos para cada tipo de restos a pagar, entre os exercícios de 2000 a 2008.

Sobre a tabela 8 e as figuras 4 e 5, é possível fazer as seguintes análises:

- Para restos a pagar processados, os cancelamentos não chegam a 30\%, como era de se esperar, pois se tratam de despesas já liquidadas nos exercícios anteriores, isto é, já houve a entrega dos bens ou serviços por parte do credor e o valor devido já é conhecido.

- Para restos a pagar não processados, os cancelamentos já chegaram a quase $75 \%$ em 2004, o que também é natural por se tratar de despesas que foram inscritas antes da entrega dos bens ou serviços contratados, mas mantém-se por volta de $30 \%$ na média dos exercícios de 2000 a 2008.

No entanto, há pouca diferença entre o percentual de restos a pagar processados pagos a cada exercício em relação ao percentual de restos a pagar não processados, chegando este percentual ser maior para o montante não processado em alguns exercícios. Considerando a média, a diferença é de menos de $5 \%$.

Albuquerque, Feijó e Medeiros (2008) recomenda que os restos a pagar não processados não sejam lançados no resultado do exercício, por tratar-se de despesas não efetivadas e sujeitas a cancelamento. Mas o resultado expresso nos gráficos 9 e 10 demonstram que, apesar de os cancelamentos do montante não processado terem sido percentualmente três vezes maiores do que os cancelamentos dos restos a pagar processados, 
o montante pago é quase equivalente. Assim, os últimos exercícios demonstram que esta recomendação deveria ser repensada.

Por fim, nas tabelas 9 e 10 a apuração do resultado primário para o setor público consolidado é recalculada, considerando neste recálculo os Restos a Pagar inscritos a cada exercício. Para esta nova apuração, foram subtraídos para cada exercício financeiro os Restos a Pagar inscritos em exercícios anteriores e pagos no exercício corrente, e foram acrescidos os Restos a Pagar inscritos pelo exercício para pagamento em exercícios posteriores. Também foram considerados constantes todos os demais montantes de receita e despesa, além dos resultados de Estados e Municípios, Empresas Estatais, Banco Central e Previdência. Os dados referentes ao Produto Interno Bruto (PIB) e à apuração oficial do Resultado Primário do Setor Público foram obtidos das séries históricas disponibilizadas pelo Banco Central do Brasil.

\begin{tabular}{|c|c|c|c|c|c|c|c|}
\hline \multicolumn{8}{|c|}{$\begin{array}{c}\text { Tabela } 9 \text { - Cálculo do Resultado Primário do Setor Público Consolidado considerando os } \\
\text { Restos a Pagar inscritos no exercício }(2003-2008)\end{array}$} \\
\hline \multirow{2}{*}{ Exercício } & \multirow{2}{*}{$\begin{array}{c}\text { PIB } \\
\begin{array}{c}\text { R\$ } \\
\text { bilhões }\end{array}\end{array}$} & \multicolumn{2}{|c|}{$\begin{array}{c}\text { Resultado Primário } \\
\text { Oficial }\end{array}$} & \multirow{2}{*}{$\begin{array}{l}\text { Meta* } \\
\% \text { PIB }\end{array}$} & \multicolumn{2}{|c|}{$\begin{array}{l}\text { Resultado Primário } \\
\text { Recalculado }\end{array}$} & \multirow{2}{*}{$\begin{array}{c}\begin{array}{c}\text { Diferença } \\
\text { em relação } \\
\text { à Meta }\end{array} \\
\% \text { PIB }\end{array}$} \\
\hline & & $\begin{array}{c}\mathbf{R} \$ \\
\text { bilhões }\end{array}$ & $\%$ PIB & & $\begin{array}{c}\mathbf{R} \$ \\
\text { bilhões }\end{array}$ & $\%$ PIB & \\
\hline 2003 & $1.699,95$ & 66,17 & $3,89 \%$ & $3,80 \%$ & 50,07 & $2,95 \%$ & $0,85 \%$ \\
\hline 2004 & $1.941,50$ & 81,11 & $4,18 \%$ & $3,80 \%$ & 72,62 & $3,74 \%$ & $0,06 \%$ \\
\hline 2005 & $2.147,24$ & 93,51 & $4,35 \%$ & $3,80 \%$ & 69,47 & $3,24 \%$ & $0,56 \%$ \\
\hline 2006 & $2.369,80$ & 90,14 & $3,80 \%$ & $3,80 \%$ & 67,76 & $2,86 \%$ & $0,94 \%$ \\
\hline 2007 & $2.597,61$ & 101,61 & $3,91 \%$ & $3,80 \%$ & 64,99 & $2,50 \%$ & $1,30 \%$ \\
\hline 2008 & $2.889,72$ & 118,04 & $4,08 \%$ & $3,80 \%$ & 58,18 & $2,01 \%$ & $1,79 \%$ \\
\hline
\end{tabular}

Tabela 10 - Montante de Restos a Pagar considerados no recálculo do Resultado Primário (2003 - 2008)

\begin{tabular}{c|c|c|c|c|c|c}
\hline \multirow{2}{*}{ Exercício } & \multicolumn{2}{|c|}{$\begin{array}{c}\text { Restos a Pagar Inscritos } \\
\text { pelo exercício }\end{array}$} & \multicolumn{2}{c|}{$\begin{array}{c}\text { Restos a Pagar Pagos } \\
\text { durante o exercício }\end{array}$} & \multicolumn{2}{c}{$\begin{array}{c}\text { Diferença entre o } \\
\text { Resultado Primário } \\
\text { recalculado o oficial }\end{array}$} \\
\cline { 2 - 7 } & $\mathbf{R}$ bilhões & $\%$ PIB & R\$ bilhões & $\%$ PIB & R\$ bilhões & $\%$ PIB \\
\hline 2003 & 25,04 & $1,47 \%$ & 8,93 & $0,53 \%$ & 16,10 & $0,95 \%$ \\
\hline 2004 & 20,35 & $1,05 \%$ & 11,86 & $0,61 \%$ & 8,49 & $0,44 \%$ \\
\hline 2005 & 36,73 & $1,71 \%$ & 12,69 & $0,59 \%$ & 24,04 & $1,12 \%$ \\
\hline 2006 & 43,41 & $1,83 \%$ & 21,03 & $0,89 \%$ & 22,38 & $0,94 \%$ \\
\hline 2007 & 61,93 & $2,38 \%$ & 25,31 & $0,97 \%$ & 36,62 & $1,41 \%$ \\
\hline 2008 & 94,56 & $3,27 \%$ & 34,70 & $1,20 \%$ & 59,85 & $2,07 \%$ \\
\hline
\end{tabular}


A tabela 9 indica que, pela apuração oficial, sob regime de caixa, a meta de resultado primário foi alcançada para todos os exercícios financeiros analisados. Mas ao recalcular o Resultado Primário considerando o montante de Restos a Pagar inscritos, a meta não seria alcançada em nenhum destes exercícios. Nota-se também que o resultado recalculado vem se afastando progressivamente da meta desde 2004.

A tabela 10 demonstra a diferença entre o valor do Resultado Primário oficial e o recalculado. Esta diferença corresponde exatamente ao montante do superávit primário oficialmente apurado que está comprometido com as despesas primárias inscritas em Restos a Pagar e que, por este motivo, não pode ser direcionado ao serviço da dívida. 


\section{4. - CONCLUSÕES}

O Resultado Primário do Governo Federal objetiva medir como as ações correntes afetam o seu endividamento líquido, e a apuração de um superávit primário deveria ser direcionado para a redução deste endividamento. No entanto, observou-se que parte do que é apurado como superávit fica comprometido com as despesas inscritas em Restos a Pagar. Isso ocorre por conta da metodologia utilizada para a apuração dos resultados fiscais do Governo Federal. Atualmente, estes indicadores são calculados pelos totais de receitas arrecadadas e despesas pagas no exercício, ou seja, pelo regime de caixa, desconsiderando as despesas legalmente empenhadas no exercício, mas não pagas.

Verificou-se que o estoque total de Restos a Pagar, somando os processados e os não-processados, têm aumentado progressivamente desde 2004, quando comparadas com a dotação orçamentária autorizada na LOA a cada exercício. Um aumento do volume de restos a pagar é preocupante, pois estas despesas concorreriam com a execução financeira do orçamento do exercício corrente. Isto porque, na prática, inscrever Restos a Pagar significa comprometer receitas futuras com o pagamento de compromissos assumidos no passado.

Ao detalhar o estoque de Restos a Pagar por grupo de despesa, observou-se também que os grupos "Pessoal e Encargos Sociais", "Juros e Encargos da Dívida” e "Amortização da Dívida" apresentam baixa representatividade dentre as despesas inscritas em Restos a Pagar. Por serem despesas limitadas por Lei, possuem um baixo grau de discricionariedade pelo governo.

Inversamente, a maior concentração de inscrições ocorre para os grupos de despesa “Outras Despesas Correntes" e "Investimentos", e de forma esporádica para o grupo de despesa "Inversões Financeiras". Estas despesas teriam um grau de discricionariedade maior e, por isso, há mais liberdade para a limitação de empenho para estes grupos.

Dentre os motivos que levam ao aumento de inscrições em Restos a Pagar, a limitação do empenho, que retarda a liberação do crédito concedido na LOA para alguns projetos e serviços, é um dos mais significativos. $O$ atraso na liberação do crédito orçamentário pode impossibilitar a execução completa da despesa dentro do exercício financeiro, levando a inscrição da parcela não-concluída em Restos a Pagar. O efeito da limitação do empenho pôde ser observado para os grupos "Outras Despesas Correntes", "Inversões Financeiras" e "Investimentos". 
Outro motivo, identificado na análise do grupo "Investimentos", refere-se aos efeitos do PPI, Programa Piloto de Investimentos e PAC, Programa de Aceleração do Crescimento. As despesas dos projetos incluídos no PPI e PAC não são submetidas a limite de empenho, pois se tratam de projetos prioritários com tratamento especial determinado na LDO. No entanto, são, em sua maioria, projetos complexos e de longa duração, e o acúmulo de despesas destes projetos inscritas em Restos a Pagar, seria explicado pelo próprio ritmo de execução dos mesmos e pela dificuldade de se encaixar projetos de longa duração em orçamentos anuais.

Portanto, tomando como base o que foi observado e considerando a busca pela transparência da política fiscal, acreditamos que as apurações dos resultados fiscais deveriam considerar todo o estoque de restos a pagar inscritos no exercício, para que indiquem verdadeiramente a saúde fiscal do país. 


\section{REFERÊNCIAS}

ALBUQUERQUE, C.M.; FEIJÓ, P.H.S.; MEDEIROS, M.B. Gestão de Finanças Públicas: Fundamentos e Práticas de Planejamento, Orçamento e Administração Financeira com Responsabilidade Fiscal. 2a ed. Brasília, DF. Coleção Gestão Pública, 2008.

BRASIL. Constituição da República Federativa do Brasil (1988). Texto consolidado até a Emenda Constitucional n ${ }^{\circ} 56$ de 20 de dezembro de 2007.

Disponível em:

http://www.planalto.gov.br/ccivil_03/Constituicao/Constituiçao.htm. Acesso em: 04 fev. 2009.

Lei $n^{0}$ 4.320, de 17 de março de 1964. Estatui Normas Gerais de Direito Financeiro para elaboração e controle dos orçamentos e balanços da União, dos Estados, dos Municípios e do Distrito Federal.

Disponível em:

http://www.planalto.gov.br/ccivil_03/LEIS/L4320.htm. Acesso em: 04 fev. 2009.

Lei complementar $n^{0}$ 101, de 4 de maio de 2000. Estabelece normas de finanças públicas voltadas para a responsabilidade na gestão fiscal e dá outras providências.

Disponível em:

http://www.planalto.gov.br/CCIVIL/Leis/LCP/Lcp101.htm. Acesso em: 04 fev. 2009.

Decreto $\mathbf{n}^{0}$ 6.025, de 22 de janeiro de 2007. Institui o Programa de Aceleração do Crescimento - PAC, o seu Comitê Gestor, e dá outras providências.

Disponível em:

http://www.planalto.gov.br/ccivil_03/_Ato2007-2010/2007/Decreto/D6025.htm. Acesso em 07 jun. 2009.

BRASIL, Ministério da Fazenda. Secretaria do Tesouro Nacional e Ministério do Planejamento, Orçamento e Gestão. Secretaria de Orçamento Federal. Portaria Interministerial STN/SOF $\mathbf{n}^{\mathbf{0}}$ 163, de 4 de maio de 2001. Dispõe sobre as normas gerais de consolidação das Contas Públicas no âmbito da União, Estados, Distrito Federal e Municípios, e dá outras providências.

Disponível em:

http://www.tesouro.fazenda.gov.br/legislacao/download/contabilidade/portarias325e519.PDF. Acesso em: 20/05/2009

GIAMBIAGI, F. 18 anos de política fiscal no Brasil: 1991/2008. Economia Aplicada, Ribeirão Preto, v. 12, n. 4, p. 535-580, out./dez. 2008.

Disponível em:

http://www.scielo.br/scielo.php?script=sci_arttext\&pid=S1413-80502008000400002\&lng= pt\&nrm=iso. Acesso em: 03 fev. 2009. 
HENRIQUES, L.G.P. Política fiscal recente no Brasil: a evolução do regime de metas de superávit fiscal. 2006. Trabalho apresentado ao XI Congreso Internacional del CLAD sobre la Reforma del Estado y de la Administración Pública, Cidade de Guatemala, 2006.

Disponível em:

http://www.clad.org.ve/fulltext/0055409.pdf. Acesso em: 03 fev. 2009.

SILVA, A.; PIRES, M.C.C. Dívida pública, poupança em conta corrente do governo e superávit primário: uma análise de sustentabilidade. Revista de Economia Política, São Paulo, v. 28, n. 4, p. 612-630, out./ dez. 2008.

Disponível em:

http://www.scielo.br/pdf/rep/v28n4/v28n4a05.pdf. Acesso em: 03 fev. 2009.

SILVA, M.C. Despesas públicas: reflexos da inscrição de restos a pagar no balanço orçamentário do governo federal. Revista Brasileira de Contabilidade. CFC. Brasília, ano XXXII, n. 141, p. $59-67,2003$.

Disponível em:

http://www.esuda.com.br/coord/cont/artigos/restos\%20a\%20pagar\%20reflexos_RBC.pdf. Acesso em: 03 fev. 2009. 